University of Nebraska - Lincoln

DigitalCommons@University of Nebraska - Lincoln

Faculty Publications from the Department of Electrical \& Computer Engineering, Department Electrical and Computer Engineering

2011

\title{
A Novel Sol-Gel Route To Pinhole-Free Iron Sulfide Thin Films
}

\author{
S. Kment \\ University of Nebraska-Lincoln \\ H. Kmentova \\ University of Nebraska-Lincoln
}

A. Sarkar

University of Nebraska-Lincoln

Rodney J. Soukup

University of Nebraska-Lincoln, rsoukup1@unl.edu

Natale J. Ianno

University of Nebraska-Lincoln, nianno1@unl.edu

See next page for additional authors

Follow this and additional works at: https://digitalcommons.unl.edu/electricalengineeringfacpub

Part of the Electrical and Computer Engineering Commons

Kment, S.; Kmentova, H.; Sarkar, A.; Soukup, Rodney J.; Ianno, Natale J.; Krysa, J.; Hubicka, Z.; Olejnicek, J.; Exstrom, C. L.; and Darveau, S. A., "A Novel Sol-Gel Route To Pinhole-Free Iron Sulfide Thin Films" (2011). Faculty Publications from the Department of Electrical and Computer Engineering. 216.

https://digitalcommons.unl.edu/electricalengineeringfacpub/216

This Article is brought to you for free and open access by the Electrical \& Computer Engineering, Department of at DigitalCommons@University of Nebraska - Lincoln. It has been accepted for inclusion in Faculty Publications from the Department of Electrical and Computer Engineering by an authorized administrator of DigitalCommons@University of Nebraska - Lincoln. 


\section{Authors}

S. Kment, H. Kmentova, A. Sarkar, Rodney J. Soukup, Natale J. Ianno, J. Krysa, Z. Hubicka, J. Olejnicek, C. L. Exstrom, and S. A. Darveau 


\title{
A NOVEL SOL-GEL ROUTE TO PINHOLE-FREE IRON SULFIDE THIN FILMS
}

\author{
S. Kment ${ }^{1,2}$, H. Kmentova ${ }^{1,3}$, A. Sarkar ${ }^{1}$, R. J. Soukup ${ }^{1}$, N. J. lanno ${ }^{1}$, J. Krysa ${ }^{4}$, Z. Hubicka ${ }^{5}$, J. Olejnicek ${ }^{5,6}$, \\ C. L. Exstrom ${ }^{6}$ and S. A. Darveau ${ }^{6}$ \\ ${ }^{1}$ Department of Electrical Engineering, University of Nebraska-Lincoln, Lincoln, NE, USA \\ ${ }^{2}$ RCPTM, Faculty of Science, Palacky University, 17. listopadu 12, 77146 Olomouc, Czech Republic \\ ${ }^{3}$ Institute of Chemical Process Fundamentals, Academy of Sciences of the Czech Republic, Prague, Czech Republic \\ ${ }^{4}$ Institute of Chemical Technology - ICT Prague, Prague, Czech Republic \\ ${ }^{5}$ Institute of Physics, Academy of Sciences of the Czech Republic, Prague, Czech Republic \\ ${ }^{6}$ Department of Chemistry, University of Nebraska at Kearney, Kearney, NE, USA
}

\begin{abstract}
The general purpose of the study is to fabricate and improve upon $\mathrm{FeS}_{2}$ thin films which can be used as the photon absorber layer for a heterojunction or homojunction solar cell. This work deals with the preparation of the pyrite by an unconventional sol-gel approach. Thin pyrite films were prepared by sulfurizing the iron oxide films previously deposited through the sol-gel method using iron (III) chloride as a precursor. The structural, morphological, electronic and optical properties of the deposited films were determined using X-ray diffraction (XRD), Raman spectroscopy, scanning electron microscopy, Auger electron spectroscopy (AES), UV-Vis absorption spectroscopy, Hall effect and profilometry. The effects of annealing and sulfurization temperatures were studied. The work was also devoted to the research of sodium diffusion from the substrate due to the thermal treatment and its affect on the pyrite films functionality.
\end{abstract}

\section{INTRODUCTION}

In recent years, iron disulfide has attracted considerable attention as a candidate for alternative solar cell materials. The very high absorption coefficient, $\alpha=6 \times 10^{5} \mathrm{~cm}^{-1}$ for $\lambda$ $=633 \mathrm{~nm}$ [1] and the composition of abundant, cheap and non-toxic elements makes pyrite an interesting material for thin-film solar cells [2]. Iron disulfide has a bandgap energy of $E_{g}=0.95 \mathrm{eV}$, [3] somewhat less than the ideal. However, a thorough modeling of the potential of pyrite indicates that efficiencies of $20 \%$ are possible [4]. It is interesting to note that the model used here included a bandgap of only $0.8 \mathrm{eV}$, so potential efficiencies are even greater. Despite these favorable physical properties, the conversion efficiencies of pyrite thin film solar cells have been disappointing and an incentive for further study. In this laboratory pyrite thin films have previously been prepared by several methods such as sputtering, sulfurization of sputtered iron or iron oxide layers [5], and chemical bath deposition [6].

A simple method should be developed for the preparation of pyrite thin films by using non-vacuum, low-cost equipment. Thin films described in this paper have been obtained by sulfurization of layers prepared using a sol-gel method. It has several advantages: simplicity, treatment of large areas, easy control of film thickness, use of metallic and nonmetallic substrates and low cost.

The main advantages of thin film pyrite solar cells would be a low material consumption and a fast and low cost production process. It is still unknown which structure would be the most favorable, a pn homojunction, a p-i-nstructure or a pn heterojunction. A promising technique, the sol-gel method, for non-vacuum growth of pyrite thin films is reported here. The results stimulate further experiments and offer the opportunity for the preparation of solar cells from pyrite.

\section{EXPERIMENTAL PROCEDURES}

\section{Preparation of thin films}

First the sol-gel procedure was employed in the preparation of the $\mathrm{Fe}_{2} \mathrm{O}_{3}$ thin films which were further sulfurized in order to obtain pyrite thin films. Iron oxide thin films were synthesized according to the following procedure. Iron(III) nitrate $(2.5 \mathrm{~g})$ was dissolved in ethyl alcohol $(10 \mathrm{ml})$ and used as a molecular precursor of $\mathrm{Fe}_{2} \mathrm{O}_{3}$. Then, $2 \mathrm{ml}$ of propylene oxide was dropped slowly into the solution and after a few minutes the solution turned dark. The hydrolysis of inorganic Fe(III) solutions consists of (a) formation of low-molecular-weight species; (b) further condensation to form a red cationic polymer; (c) aging of the polymer causing conversion to oxide phases; (d) precipitation of oxide phases directly from lowmolecular-weight precursors. The prepared solution was used to spin coat previously cleaned substrates at 2200 rpm. By a single spin, thin $(\sim 50 \mathrm{~nm})$ layers were obtained; whereas thicker layers were obtained by multiple coatings. After each spin coating, thermal treatments were performed raising the temperature at approximately 100 ${ }^{\circ} \mathrm{C} / \mathrm{h}$ and keeping the temperature at different levels for 1 hour. Soda lime glass slides were used as the substrates.

Next, the calcinated layers prepared by the sol-gel method were sulfurized in an evacuated quartz tube using a Rapid Thermal Annealing (RTA) irradiation lamp as a heating source. The RTA system allows precise programming of a thermal annealing ramp. The temperature was increased at the rate of $150^{\circ} \mathrm{C} / \mathrm{min}$ up to $450^{\circ} \mathrm{C}$. At this temperature 
level, the samples dwelled for 15 minutes and then the RTA was turned off allowing the temperature to decrease slowly to ambient temperature. During the sulfurization, the samples were kept in a graphite boat together with sulfur powder. The sulfur amount of $1 \mathrm{~g}$ was the same for all the experiments. The boat was placed in the quartz tube, in which it was connected via a thermocouple to a station operating the RTA lamp. The tube was first evacuated and then filled with Argon. The influence of two parameters, temperature and time of sulfurization, was studied. The sulfurization temperature was varied between $400{ }^{\circ} \mathrm{C}$ and $500{ }^{\circ} \mathrm{C}$ (heating rate $150{ }^{\circ} \mathrm{C} / \mathrm{min}, 1$ hour dwelling time in these experiments) and the sulfurization time was constantly decreased from 5 hours to $15 \mathrm{~min}$ at the temperature of $450{ }^{\circ} \mathrm{C}$, the temperature which yielded the best results.

\section{Thin Film Characterization}

Raman spectra were recorded by means of a back scattering Raman microscope (Renishaw) with the excitation laser wavelength of $514 \mathrm{~nm}$. X-ray diffraction patterns were taken on an XRD diffractometer - Rigaku D/ Max-B diffractometer (Cu Ka radiation $~ 1.544$ Angstroms, $\left.2 \Theta=20-70^{\circ}\right)$. The layers' morphologies and grain sizes were imaged using scanning electron microscopy (Hitachi S4700). The UV/Vis spectrophotometer (Perkin-Elmer, model Lambda 900) was employed for detecting absorption edges of the prepared samples. Chemical composition of the layers was analyzed by Auger Electron Spectroscopy - AES (Physical Electronics 560 AES/XPS).

\section{RESULTS AND DISCUSSION}

The sol-gel method appears to be a suitable candidate to produce high-quality pyrite layers. Fig. 1 shows the Raman spectrum of a five-layer $\alpha-\mathrm{Fe}_{2} \mathrm{O}_{3}$ coating after sulfurization at different temperatures.

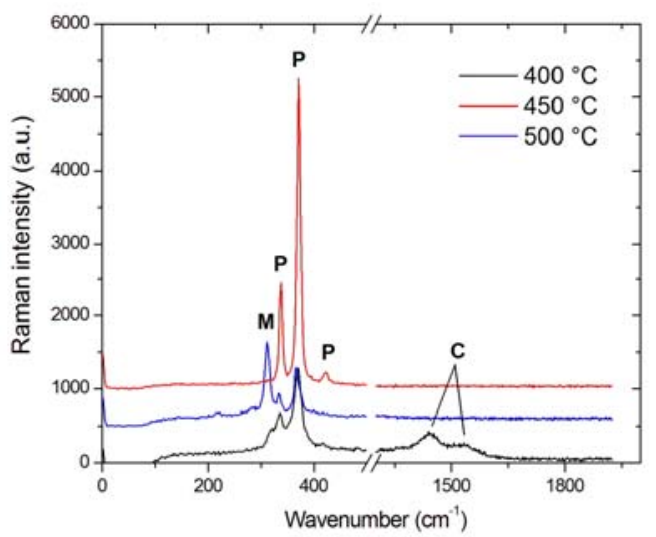

Fig. 1: Raman spectra of $\mathrm{FeS}_{2}$ films sulfurized at different temperatures for one hour. In the graph, $P$ Pyrite, M - Marcasite and C - Carbon.

Using the temperature of $400{ }^{\circ} \mathrm{C}$ led to the chemical sulfurization of hematite phase film to pyrite $\mathrm{FeS}_{2}$ (hereafter sample L1). Three basic Raman bands of pyrite, corresponding to the peaks at $339 \mathrm{~cm}^{-1} \sim E_{g}, 374 \mathrm{~cm}^{-1} \sim A_{g}$ and $426 \mathrm{~cm}^{-1} \sim \mathrm{T}_{\mathrm{g}}$, are observed in the spectrum (see Fig. 1). However, the chemical transformation is incomplete. This is demonstrated by the presence of the two peaks at around $1500 \mathrm{~cm}^{-1}$, which are apparently attributed to the residual organic carbon coming from the sol-gel reagents. The low intensities of pyrite Raman peaks probably reflect the low extent of crystallinity of the sample. Contrary to L1, any peaks located at the position of carbon Raman bands are not seen in case of the sample sulfurized at $500{ }^{\circ} \mathrm{C}$ (sample L2). On the other hand different crystallographic structure corresponding to marcasite $\mathrm{FeS}_{2}$ was revealed in this spectrum. The phase transformation is obviously due to the higher sulfurization temperature. The best result, in terms of desired pyrite crystal phase, was accomplished by performing the sulfurization at $450{ }^{\circ} \mathrm{C}$. It is known that at this temperature, close to the sulfur boiling point, it is in its cyclic $\mathrm{S}_{8}$ form, which is the most suitable for the sulfurization processes.

Further, the effect of the sulfurizarion duration on the films properties was studied. The dwelling time was varied in the range between $15 \mathrm{~min}$. and 6 hours. Somewhat surprising results were observed in Raman spectra shown in Fig. 2.

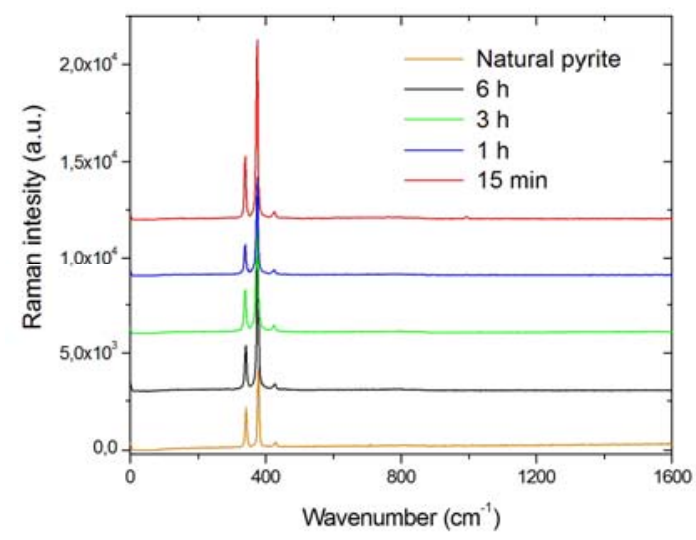

Fig. 2: Raman spectra of pyrite samples sulfurizing the hematite films at different time durations.

It is clearly seen from the graph that overall time of the sulfurization did not influence the crystallographic structure in any way. The three main Raman bands are present in every spectrum. The complete chemical transformation from the hematite to pyrite was achieved after 15 minutes. This is a very appealing condition for potential solar cell fabrication.

These films were also compared in terms of their morphological properties. The SEM images of the samples can be seen in Fig. 3. It is evident that increasing the time of sulfurization led to the formation of bigger grains aggregates, which resulted in films's greater roughness. Nevertheless, any significant defects in the films were not detected. 

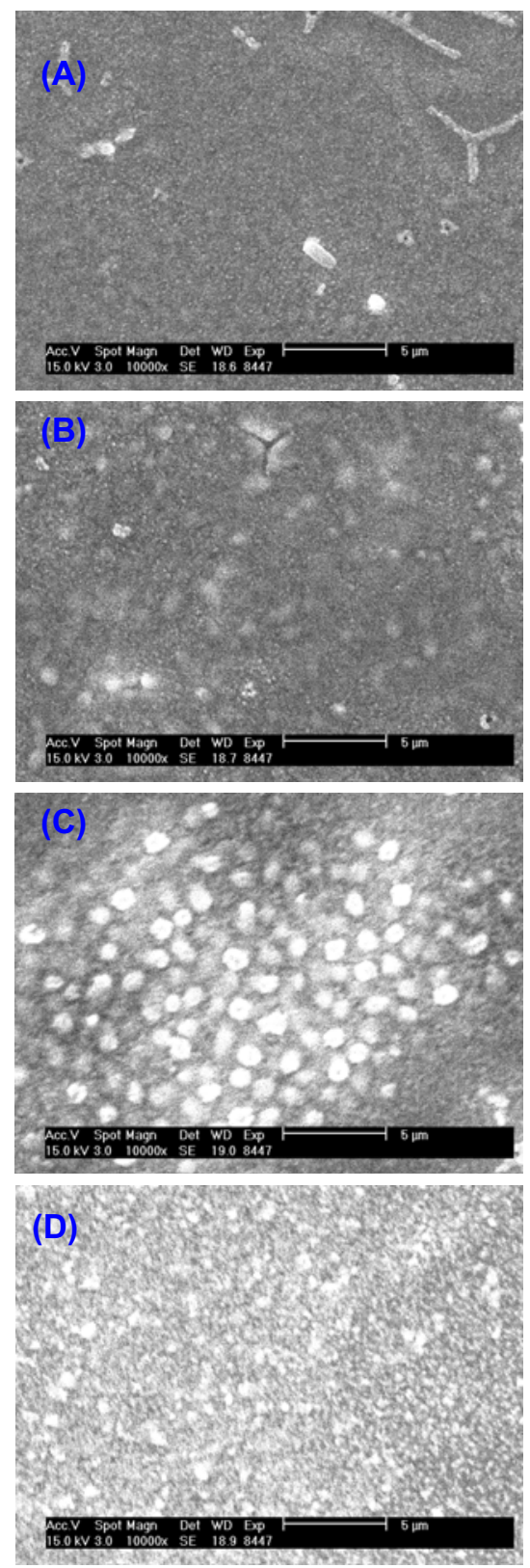

Fig 3: SEM images of the samples sulfurized at $450{ }^{\circ} \mathrm{C}$ for: (A) $15 \mathrm{~min},(B) 1 \mathrm{~h}$, (C) $3 \mathrm{~h}$ and (D) $6 \mathrm{~h}$.

Furthermore the films were also observed using XRD analysis. The results correlate with the Raman spectroscopy data. The intensity of XRD peaks, which only appeared for the pyrite phase, is almost equal for all time durations, indicating the same extent of crystallization, see Fig. 4.

The sample with five layers is of interest because its thickness is in the appropriate range for photovoltaic applications. This film was annealed five times (once after each spin coating) at $600{ }^{\circ} \mathrm{C}$ to achieve the hematite structure and further sulfurized at $450{ }^{\circ} \mathrm{C}$ for 15 minutes.
The problem encountered in films of several layers was the incorporation of $\mathrm{Na}$ in the films. The more times the sol-gel material is annealed the more likely the $\mathrm{Na}$ has of diffusing from the soda lime glass into the substrate.

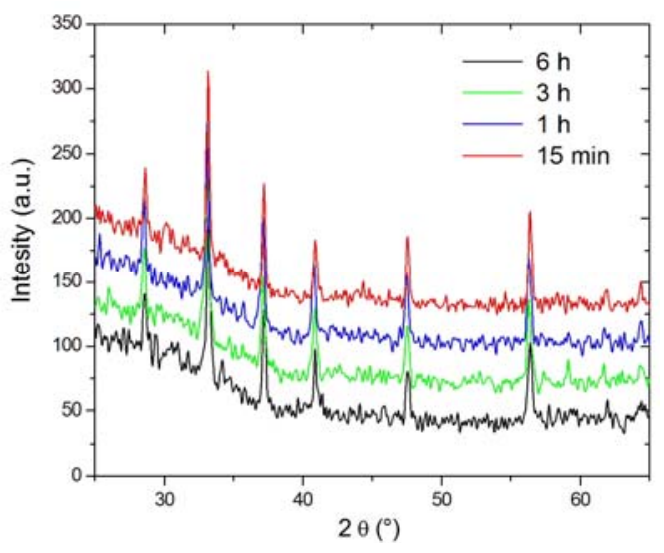

Fig. 4: XRD spectra of pyrite films prepared by sulfurizations of varying time duration.

This effect has been confirmed by glow discharge optical emission spectroscopy (GDOES) which showed considerable penetration of the $\mathrm{Na}$ into the $\mathrm{FeS}_{2}$ (see Fig. 5 ). This problem is being studied by using various barrier coatings and different substrates.

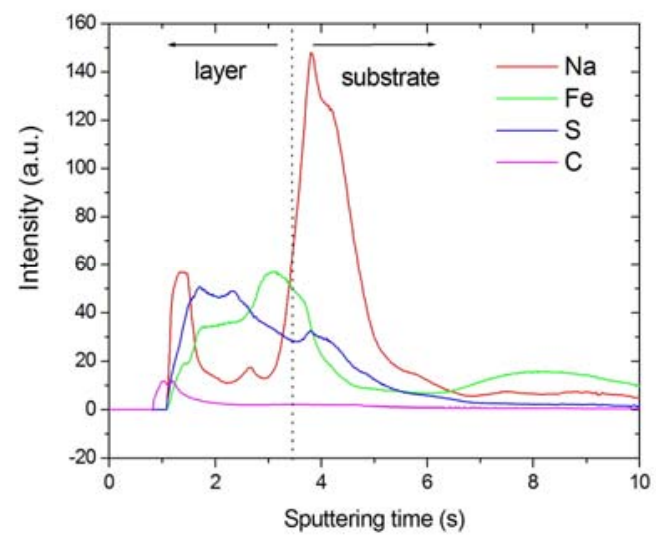

Fig. 5: GDOES elemental depth profile of the film sulfurized for $15 \mathrm{~min}$ at $450{ }^{\circ} \mathrm{C}$.

Another important diagnostic tool to determine the chemical composition of the pyrite films was AES. A typical depth profile Auger scan of the films revealed that the stoichiometry of the film was almost precisely $2(\mathrm{~S}): 1$ $(\mathrm{Fe})$, within the range of precision of the AES system and was constant through the entire film.

Because pyrite films are being studied for potential use in solar cells, their optical properties are among the most important parameters. The energy band gap value is 
critical. The intersection of the trend line for the linear portion of the Tauc curve with the energy $(x)$ axis denotes the band gap energy width. The band gap energy determined form this measurement was $0.93 \mathrm{eV}$, which is just slightly below the expected value of $0.95 \mathrm{eV}$ [3].

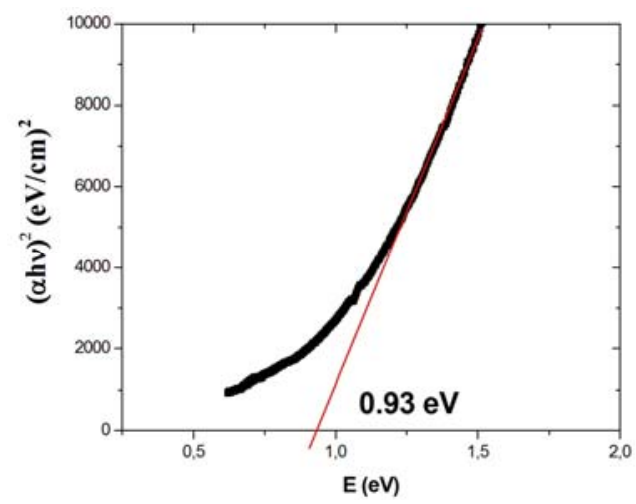

Fig. 6: Tauc plot of the film sulfurized for $15 \mathrm{~min}$ at $\mathbf{4 5 0}$ ${ }^{\circ} \mathrm{C}$. The intersection of the red line with energy axis denotes the band gap energy.

The photo-responses of the films were assessed using photoelectrochemical experiments of amperometry. For this purpose the system of conductive (Indium doped tin oxide) ITO substrate / anatase $\mathrm{TiO}_{2} / \mathrm{FeS}_{2}$ was prepared. The system was illuminated with light corresponding to band gap of $\mathrm{FeS}_{2 .}$, which served as the prime absorber sensitizing the anatase film. The system is conventional three electrode set-up of a working electrode (ITO/TiO2/FeS2), auxiliary electrode $(\mathrm{Pt})$ and a reference electrode $(\mathrm{Ag} / \mathrm{AgCl}$ in $3 \mathrm{M} \mathrm{KCl})$.

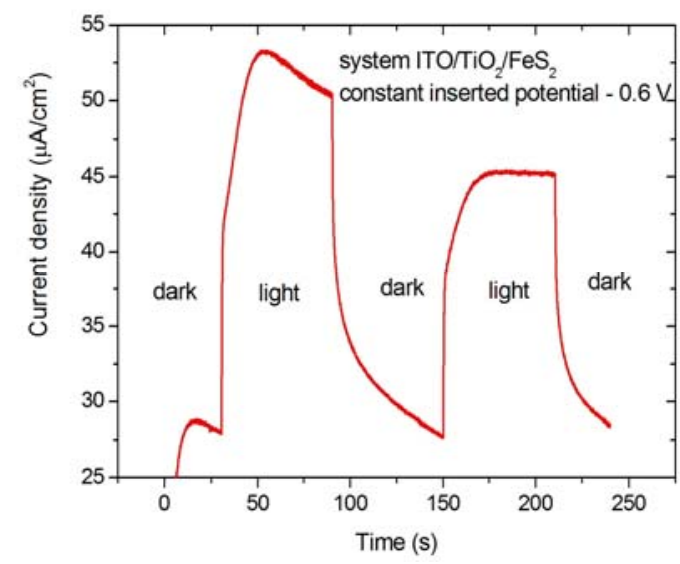

Fig. 7: Photocurrent curve - dependency on time at fixed potential of $0.6 \mathrm{~V}$.

Fig. 7 shows the dependence of current density (photocurrent) on time under a fixed potential of $0.6 \mathrm{~V}$. The rather low value of the photocurrent is probably due to the high recombination rate of the carriers (electron/hole pair) and sulfur deficiency in the lattice.

\section{CONCLUSION}

The novel approach for the production of the pinhole free thin films of $\mathrm{FeS}_{2}$ pyrite was described. The method is based on the sol-gel preparation of $\alpha-\mathrm{Fe}_{2} \mathrm{O}_{3}$ (hematite) thin layers and their subsequent chemical sulfurization. The effects of thermal annealing of hematite films and temperature of the sulfurization on the properties of the films is discussed. It is apparent that this sol-gel method produces promising photovoltaic absorber material.

\section{ACKNOWLEDGEMENTS}

We would like to acknowledge the financial support of the Department of Energy, grant No. DE-FG36-08G088007, the Nebraska Center for Energy Sciences Research and the Deparrment of Electrical Engineering at the University of Nebraska-Lincoln in the United States and the Operational Program Education for Competitiveness European Social Fund (project CZ.1.07/2.3.00/20.0017 of the Ministry of Education, Youth and Sports of the Czech Republic), the Grant Agency of Academy of Sciences of the Czech Republic (project - KAN400720701), and the Ministry of Education of the Czech Republic (project Nanopin 1M0577) in the Czech Republic.

\section{REFERENCES}

[1] K. Buker, N. Alonso-Vante and H. Tributsch, "Photovoltaic Output Limitation of n-FeS 2 (pyrite) Schottky Barriers: A Temperature-Dependent Characterization", J. Appl. Phys. 72, 1992, pp. 5721-5728.

[2] Cyrus Wadia, A. Paulalvisatos and Daniel M. Kammen, "Materials Availability Expands the Opportunity for LargeScale Photovoltaics Deployment", Environ Sci. Technol. 43, 2009, pp. 2072-2077.

[3] S. Fiechter, M. Birkholz. A. Hartmann, P. Dulski, H. Tributsch and R. J. D. Tikkey, "The Microstructure and Stoichiometry of Pyrite FeS $_{2-x}$ ", J. Mater. Res. 7, 1992, pp. 1829-1838.

[4] P. P. Altermat, T Kiesewetter, K. Ellmer and $\mathrm{H}$. Tributsch, "Specifying Targets of Future Research in Photovoltaic Devices Containing Pyrite $\left(\mathrm{FeS}_{2}\right)$ by Numerical Modelling", Sol. Energy Mtrls. And Sol. Cells 71, 2002, pp. 181-195.

[5] R. J. Soukup, P. Prabukanthan, N. J. Ianno, A. Sarkar, C. A. Kamler, and D. G. Sekora, "Formation of Pyrite $\left(\mathrm{FeS}_{2}\right)$ Thin Films by Thermal Sulfurization of DC Magnetron Sputtered Iron", J. Vac. Sci. Technol. A 29, on line, 2011.

[6] P. Prabukanthan, R. J. Soukup, N. J. Ianno, A. Sarkar, S. Kment, H. Kmentova, C. A. Kamler, C. L. Exstrom, J. Olejnicek, and S. A. Darveau, "Chemical Bath Deposition 
of Iron Sulfide Thin Films for Photovoltaic Applications,

Crystallographic and Optical Properties", Proc. $35^{\text {th }}$ IEEE

Photovoltaic Specialists Conference, 2010, pp. 2965 -

2969. 